\title{
Wave climate and power distribution around a rocky island: Alcatrazes, Brazil
}

\author{
Leonardo Silveira Takase ${ }^{1,2}$, Luiza Paschoal Stein ${ }^{1,2}$, Natasha Travenisk Hoff',2@ ${ }^{1}$ Eduardo Siegle ${ }^{1, *(1)}$ \\ 1 Instituto Oceanográfico - Universidade de São Paulo - Praça do Oceanográfico, 191 - Butantã - 05508-120 - São Paulo - SP - Brazil \\ 2 Programa de Pós-Graduação em Oceanografia, Instituto Oceanográfico - Universidade de São Paulo - Praça do Oceanográfico, 191 - \\ Butantã - 05508-120 - São Paulo - SP - Brazil \\ * Corresponding author: esiegle@usp.br
}

\section{Abstract}

We investigate the distribution of the wave power around the Alcatrazes island, a protected marine reserve in southeastern Brazil, located at 20 nautical miles from the coast of São Sebastião/SP. A 14-year wave time series (2005-2018) extracted from the global WaveWatch III model, was used to obtain the offshore wave climate. Based on the wave climate, a wave propagation model (Delft3D) was applied in order to obtain nearshore information. The most frequent waves are from the east, southeast and south, with heights between 1.0 and $2.0 \mathrm{~m}$ and periods of 7 to $10 \mathrm{~s}$. Due to dominant wave direction incidence, the wave power is higher at the more exposed eastern side of the island, with its lee side becoming shadowed from the main wave trains. Magnitudes vary seasonally, with winter and autumn presenting more energetic southerly waves and consequent higher wave power along the rocky island. The wave power distribution is a consequence of the incident wave characteristics and the geomorphology of the island. Our findings are the first assessment of the local wave climate and wave power distribution along the rocky shores of Alcatrazes island, providing important background information for understanding different aspects of its functioning and management.

Descriptors: Wave modelling, Hydrodynamics, Wave power, Wave climate, Rocky island, Delft3D.

\section{INTRODUCTION}

Archipelagos are environments of great ecological and geological importance, where the waves are determining factors for the maintenance of biotic and abiotic processes (Tolvanen and Suominen, 2005). There are several studies that correlate the exposure of waves with the maintenance of the rocky coast community (e.g., Dalby et al., 1978; Gaylord, 1999; Gibbons, 1988; Jones and Demetropoulos, 1968; Prathep et al., 2009; Rattray et al., 2015; St-Pierre and Gagnon, 2015; Wright et al., 2018), shaping their distribution and adaptation, for example. Waves also have a primary role of introducing energy in coastal

Submitted: 23-September-2020

Approved: 24-February-2021

Associate Editor: Curtis Collins

C 2021 The authors. This is an open access article distributed under the terms of the Creative Commons license. regions (Pianca et al., 2010), being able to change the morphology of beaches (e.g., Ortega-Sánchez et al., 2008; Stein \& Siegle, 2019), interact with rocky coasts (e.g., Hall et al., 2008; Thébaudeau et al., 2013; Vann Jones et al., 2018), and other coastal environments. Thus, the study of the incident waves in archipelagos is of great relevance for the understanding of the oceanographic processes acting in these economically and biologically important ecosystems.

Currently, when no measured data is available, the characterization of the wave pattern of a coastal region is possible due to the existence of global wave generation numerical models, such as WaveWatch III(WW3), developed by the NCEP (National Centers for Environmental Prediction) of NOAA (National Oceanic and Atmospheric Administration), coupled with regional models, such as Delft3D, developed by Deltares. Usually, data from global numerical models 
do not have the high spatial resolution required for coastal areas. Such datasets are extracted, reanalyzed, and used as input for local models, whose results are often compared with data from moored instruments for a shorter period of time to validate them (for example in wave energy studies around islands conducted by Stopa et al., 2013, 2011). There are also those who use long data series extracted from monitoring systems for wave quantification and propagation to the coast with local models (e.g., Lemke et al., 2017; Ludka et al., 2019), even though, in general, it is more difficult to obtain long time series of measured data, as a consequence of the high costs and difficulties of keeping moored instruments in coastal areas for long periods.

The Alcatrazes archipelago is located nearly 20 miles $(\sim 37 \mathrm{~km})$ off the coast of São Sebastião city in the São Paulo state, Southeastern Brazil. Home to endemic species with restricted distribution, it is a nursery and growth area for endangered marine species (e.g. Atlantoraja castelnaui) and belongs to two marine environmental protection areas (ICMBio, 2017), which makes it of high relevance for the environment. Thereby, although studies on fauna and floristic composition of its islands have already been conducted (e.g., da Rocha and Bonnet, 2009; Gallo et al., 2001; Gibran and de Moura, 2012; ICMBio, 2017; Muscat et al., 2014; Rolim et al., 2019, 2017; Visnadi and Vital, 2001), the incident waves pattern and its power distribution around the main island, Alcatrazes, have not yet been studied.

Assuming that the influence of seasonal atmospheric events causes different distributions of wave characteristics, and that at the lee side of islands the offshore wave trains undergo great transformations (Rusu et al., 2008), reducing their periods and heights (e.g., Anastasiou and Sylaios, 2013), here, these processes have been analyzed and quantified for Alcatrazes with numerical modeling, considering the logistic and environmental difficulties for obtaining in situ data. Therefore, based on numerical modeling scenarios based on offshore wave characteristics, obtained by reanalyzing a 14-year wave time series of the global model WaveWatch III, our aim is to assess the wave power distribution around the Alcatrazes island. As a precursor for the construction of the model, the offshore wave climate has also been described (and extreme waves evaluated), and could be used as input to future studies on the archipelago's hydrodynamics. Our findings may provide background information to (i) support new studies on marine flora and fauna, especially with regard to the distribution and adaptation of the benthic communities around the island, (ii) provide information for the existing management plan of the archipelago with more abiotic parameters, and (iii) identify areas of higher or lower wave exposure for studies related to the exposure to pollutants, such as oil; among others.

\section{METHODS}

\section{Study Area}

Located in the municipality of São Sebastião, on the northern coast of the state of São Paulo, the Alcatrazes Archipelago (2410 'S, 45⒎' W; Figure 1A) includes six islands, five minor islands, three shallow flats with granitic rock formation (Martins et al., 2014), and two reefs. Encompassing two non-take marine protect areas, Tupinambás Ecological Station (TES, 1987), and the Alcatrazes Wildlife Refuge (AWR, 2016), with restricted human presence (Hoff et al., 2015), the archipelago preserves a great biodiversity, sheltering the largest Brazilian nest zone of magnificent frigatebird (Fregata magnificens) and endemic terrestrial and marine species (ICMBio, 2017, 2012; Lanna et al., 2007; Nogueira et al., 2001).

The Alcatrazes archipelago has its origin related to the uplift of the Serra do Mar ridge, and its erosive regression during the Superior Cretaceous and the Paleocene, and to the subsidence of the Santos Basin (Furtado et al., 2008), resulting in a strictly rocky island with peaks ranging from 40 to $266 \mathrm{~m}$ in height (Muscat et al., 2014). Under complex oceanographic conditions, the study area is influenced by three water masses transported by the Brazil Current: Coastal Water, Tropical Water and South Atlantic Coastal Water, the latter related to coastal upwelling, leading to physical, chemical and biological consequences in the region (Castro et al., 2008; Pires-Vanin et al., 1993). Besides, flowing in opposite direction, the Brazil Coastal Current transports cold waters and sediments from the Rio de La Plata and the Lagoa dos Patos northwards, defining a transitional zone nearby São Sebastião island (Mahiques et al., 2008; De Souza and Robinson, 2004; Mahiques et al., 2011). In the archipelago, sandy sediments are predominant, with 

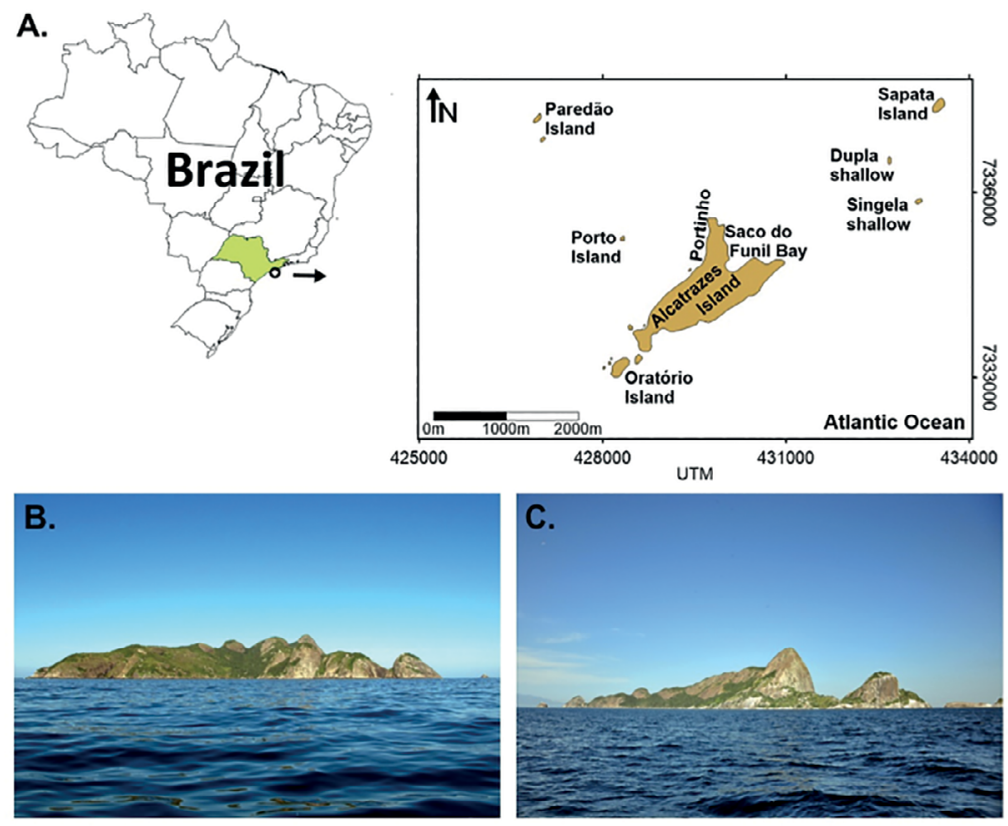

Figure 1. Study area: Alcatrazes archipelago; (A) located in southeastern Brazil, in the state of São Paulo. Focus is on the main island, Alcatrazes Island, the Saco do Funil Bay and the Portinho region. The smaller islands and shallow flats are also labeled. (B) Photo of the Alcatrazes island coast facing toward the continent. (C) Photo of the Alcatrazes Island coast facing to the open sea. Photos: Leandro Inoue Coelho.

greater contribution of gravel sediments in the immediate vicinity of the Alcatrazes island (Hoff et al., 2015).

There is no detailed bathymetric survey of the region, only Brazilian Navy Nautical Charts (DHN 23100) and local charts. The archipelago is located at the continental shelf of the state of São Paulo, at depths ranging from 30 and $45 \mathrm{~m}$. Without affecting the wave propagation, isolated reefs can be found around the islands.

Previous studies of the offshore wave climate in the State of São Paulo show predominant waves from the south and east quadrant, followed by waves from the southeast (e.g., Andrade et al., 2019; Pianca et al., 2010; Silva et al., 2016). Wave heights range from 1.0 to $2.0 \mathrm{~m}$ and predominant periods of up to $10 \mathrm{sec}-$ onds. About the wave force, in general, studies such as the one by Reguero et al., (2019) show that the average wave energy in the South Atlantic is lower than in other oceans. Pianca et al., (2010), studying the Brazilian offshore wave climate, establishes that the wave power in the southern and southeastern regions of Brazil is slightly higher than in the northern and northeastern regions, and that seasonally the energy peaks in the southeastern region occur in Autumn and Winter.
These studies relate the wave parameters found to the atmospheric dynamics and, in the study area, they are influenced by the South Atlantic convergence zone (SACZ), the South Atlantic Subtropical Anticyclone (SASA; reviewed by Reboita et al., 2019) and the passage of cold fronts to explain the offshore wave conditions. Synoptically, the cold front affects oceanographic conditions, with winds from the south quadrant. Pampuch and Ambrizzi (2015) investigation showed that about 25 to 30 frontal systems events reach the state of São Paulo. The predominance of extreme events in winter and minimal occurrences in summer is observed in the study of Gramcianinov et al. (2020), conducted using a 6-year time series of wave data (1999-2004). The work of these authors related the occurrence of extreme wave events in the southern of Brazil ahead or behind of cold fronts or along warm fronts.

Although Alcatrazes has many smaller islands, our study will focus on the largest island in the archipelago, the Alcatrazes island $\left(24^{\circ} 06^{\prime} \mathrm{S}, 45^{\circ} 43^{\prime} \mathrm{W}\right.$, Figure $1 \mathrm{~B}$ and C), which has an "y" shape (Muscat et al., 2014), with $2.75 \mathrm{~km}$ in length, and an average width of $0.6 \mathrm{~km}$; the coast is oriented northeast-southwest (Gallo et al., 2001), and is formed by rocky slopes, which represent $9.18 \%$ of its total area (ICMBio, 2017), without the presence of beaches. 


\section{Wave Climate and Extremes}

To determine the wave climate that reaches Alcatrazes and surroundings, significant height $(\mathrm{Hs})$, peak period (Tp) and peak direction (Dp) for 14 years (2005-2018) were extracted from NOAA global model WAVEWATCH-III (WW3) (Tolman, 1999), at coordinates closest to the Archipelago ( $24^{\circ} 5$ ' $\mathrm{S} ; 45^{\circ} 5^{\prime} \mathrm{W}$ ). The WW3 spatial resolution is of $1^{\circ} \times 1.25^{\circ}$ (latitude $x$ longitude) and solves the random phase spectral action density balance equation (Tolman, 1999). This model has already been used and validated in other studies (e.g., Alves et al., 2009; Bento et al., 2018; Gonçalves et al., 2020; Li et al., 2016; Pegorelli et al., 2018; Stopa et al., 2013, 2011; Sun et al., 2020).

The wave regime was subdivided into yearly and seasonal climate, considering the four climatic seasons individually according to the solstices and equinoxes of the Southern hemisphere. Initially, we estimated basic statistics such as mean, standard deviation and maximum and minimum values for each wave parameter at each of these subdivisions. Then, we analyze each parameter separately, dividing it into classes, also considering the subdivisions adopted. For the analysis of the peak direction, the data were divided into eight classes, representing the incoming wave directions. For the analysis of wave height, the data were divided into classes with $0.5 \mathrm{~m}$ variation, while the peak period data were divided into classes with $1 \mathrm{~s}$ intervals, and we consider two decimal places in both cases. From the modal class (most frequent interval of a given parameter), the typical events were determined.

Lastly, we also assess the effects of extreme events. Therefore, we use $\mathrm{Hs}$ values above the 95th percentile of the time series, and we consider extreme events as those that last for 12 hours or more, to avoid considering sporadic undulations in the time series as extreme events. The 12-hours duration of the extreme events has also been used for the south and southeast coast of Brazil by Gramcianinov et al., (2020).

\section{Numerical EXPeriments}

In order to propagate the offshore waves to shallower water and at higher spatial resolution, needed to solve waves around the island, we applied the Wave module of the Delft3D numerical model, developed by Deltares. It is based on the SWAN (Simulating Waves Nearshore) model, based on the conservation equation for spectral action density (Booij et al., 1999; Holthuijsen et al., 1993; Ris and Booij, 1999). Bottom friction, wave refraction, diffraction, shoaling, breaking and wave setup in coastal areas are all considered in the model formulation. Modeled output data (significant wave height and wave period), extracted at around $100 \mathrm{~m}$ from the coast, were used to estimate the wave power around the island.

Based on the area of interest and available bathymetry, a regular rectangular grid was created and used (Figure 2). In order to decrease the computational modeling effort, the grid has cells of $500 \times 500$ $\mathrm{m}$ in areas far from the archipelago, and in the region of interest, maximum refinement, reducing the size of the cells to $55 \times 55 \mathrm{~m}$. Four open boundaries have been used (northeast, southeast, southwest and northwest), where the most frequent wave events were included as initial condition for the simulation. This wave scenarios refer to cases with frequency of occurrence equal or greater than 5\% according to the direction and significant wave height and the most frequent peak period associated, as applied by other studies (e.g., Ambrosio et al., 2020; LavenèreWanderley \& Siegle, 2019; Siegle \& Costa, 2017; Silva et al., 2016). Thus, here we consider 43 cases defined after analyzing the general climatology of the waves ( 7 for the interannual period, 7 for autumn, 9 for summer, and 8 for spring and 8 for winter) and 4 cases for the analysis of extreme events.

\section{Wave Power}

Wave power was estimated through the relation that considers the synergistic effect between wave heights and periods. From the linear wave theory (Holthuijsen, 2007), the wave energy flux can be obtained by the product between its energy per unit area and the wave group speed (Equation 1). $P$ is given in Watts per meter [ $\mathrm{W} \mathrm{m}^{-1}$ ], $\rho$ is the water density (defined as $1,027 \mathrm{~kg} \mathrm{~m}^{-3}$ ), $g$ is the acceleration of gravity (approximately $9.8 \mathrm{~m} \mathrm{~s}^{-2}$ ), $H$ is the wave height (in meters) and $T$ is the period (in seconds).

$$
P=\frac{\rho g^{2} H^{2} T}{32 \pi}\left[\frac{\mathrm{w}}{m}\right](\text { Equation } 1)
$$

Modelled Hs and Tp results were extracted after the wave propagation to the island, at points covering the coast around the island. The wave 


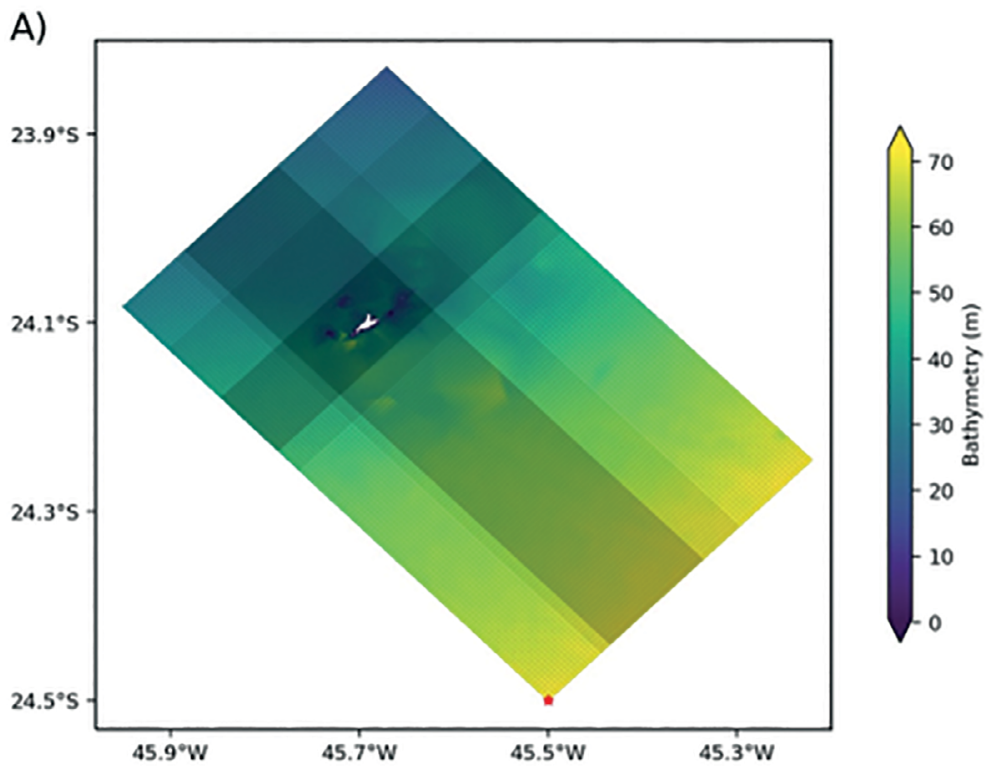

B)

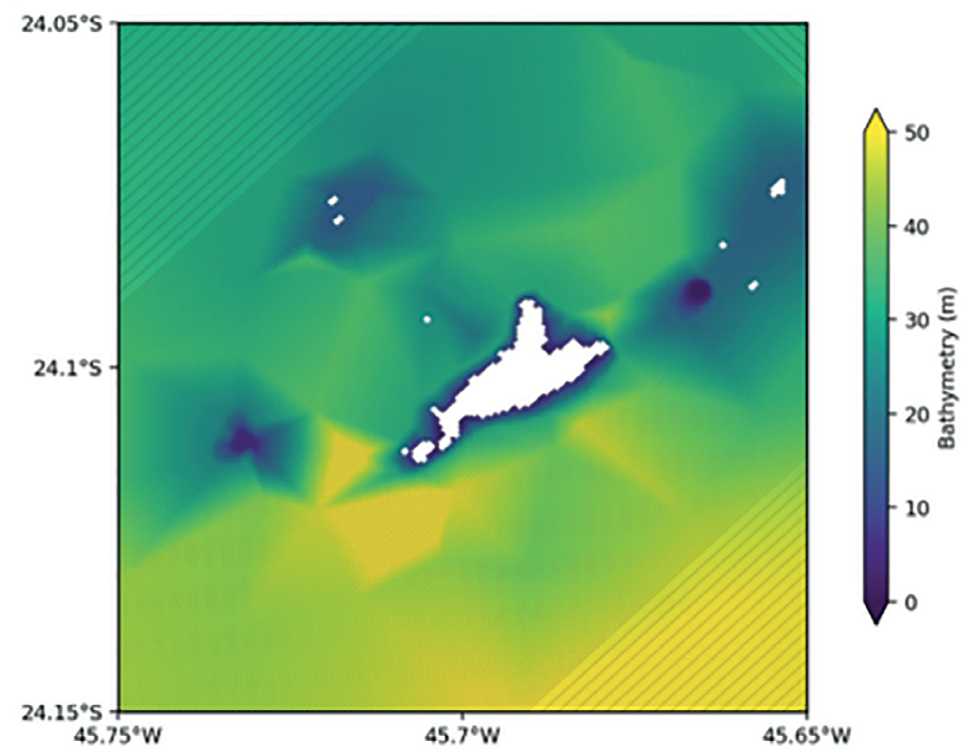

Figure 2. A) Numerical grid used for numerical modeling, with interpolated bathymetry, in meters. The blue regions are the shallowest and the green ones are the deepest. The data extraction point of WaveWatch3 is represented by the red star. B) Refined grid around Alcatrazes island.

power equation was applied to each simulation at each point, and a weighted average (Equation 2) was calculated using $P$ of each point and scenario to determine the average wave power around Alcatrazes island. Lastly, we replicate the points to the edge of the island, and interpolate the $P$ values for each point using the nearest neighbor method, generating the interannual and seasonal wave force around the island.

$$
M_{p}=\frac{\sum_{i=1 x_{i} p_{i}}^{n}}{\sum_{i=1 p_{i}}^{n}}(\text { Equation 2) }
$$

\section{RESULTS}

\section{Wave Climate and Extremes}

Analyzing the summarized wave climate statistics from the WW3 data (Table 1), we notice differences 
Table 1. Yearly and seasonal wave parameters (Hs and Tp) statistics (minimum, maximum, range, mean, variance and standard deviation) from 2005 to 2018.

\begin{tabular}{|c|c|c|c|c|c|c|c|}
\hline Parameter & Season & Min. & Max. & Range & Mean & Var & Std \\
\hline \multirow{5}{*}{$\mathrm{Hs}(\mathrm{m})$} & Yearly & 0.38 & 5.18 & 4.8 & 1.66 & 0.36 & 0.6 \\
\hline & Summer & 0.44 & 3.82 & 3.38 & 1.41 & 0.25 & 0.5 \\
\hline & Autumn & 0.38 & 5.18 & 4.8 & 1.52 & 0.38 & 0.62 \\
\hline & Winter & 0.52 & 4.88 & 4.36 & 1.63 & 0.45 & 0.67 \\
\hline & Spring & 0.62 & 4,49 & 3.87 & 1.71 & 0.28 & 0.53 \\
\hline \multirow{5}{*}{$\mathrm{Tp}(\mathrm{s})$} & Yearly & 3.18 & 19.86 & 16.68 & 9.36 & 4.33 & 2.08 \\
\hline & Summer & 2.68 & 18.43 & 15.75 & 8.59 & 3,99 & 2.00 \\
\hline & Autumn & 3.38 & 19.23 & 15.85 & 9.63 & 4.35 & 2.09 \\
\hline & Winter & 3.91 & 19.86 & 15.95 & 9.7 & 4.52 & 2.13 \\
\hline & Spring & 3.31 & 19.28 & 15.97 & 8.8 & 3.45 & 1.86 \\
\hline
\end{tabular}

between the yearly and seasonal directional wave histograms (Figure 3). The amplitude of the Dp, Hs and $\mathrm{Tp}$ data indicates that there is a considerable variability in WW3 simulated wave data, as expected. Most energetic waves reach the area from southeast, reaching maximum heights and periods of $5.2 \mathrm{~m}$ and $18.9 \mathrm{~s}$, respectively. The average wave height tends to be slightly higher during spring and winter, while summer has the lowest average (Table 1). The interannual mean wave height is $1.66 \mathrm{~m}$, which is lower than mean height at spring, and the peak period average seems to be remarkably similar seasonally and interannually, resulting in $9.4 \mathrm{~s}$ mean in the interannual wave climate. Southern quadrant waves are dominant during the year and during most seasons. Only during summer months are the easterly waves equivalent to the southern waves.

The modal intervals of $\mathrm{Hs}, \mathrm{Tp}$ and $\mathrm{Dp}$ allowed the identification of wave incidence patterns in the region adjacent to the Alcatrazes archipelago, especially when we observe $\mathrm{Hs}$ and $\mathrm{Tp}$ distributed according to the direction (Figure 3). During interannual events there is a contribution from eastern events that is confirmed during seasons, except in autumn, when there is less contribution from the east and predominantly from the south. Regarding wave heights, there is a constancy of predominant values in the range of $1.0-1.5 \mathrm{~m}$ in three of the four seasons of the year (only in spring the typical height is above other seasonal events). However, the frequencies observed in these intervals decrease from summer to winter, while waves of $1.5-2.0 \mathrm{~m}$ tend to increase in frequency until reaching maximum in spring, when they predominate. This also happens with waves of 2.0 to $2.5 \mathrm{~m}$, which reach the maximum frequency of occurrence in the same season. Interannual waves have typical periods of 8-9 s that predominate for the eastern quadrant. Although the seasonal waves vary between 7-8 $\mathrm{s}$ in summer, 9-10 $\mathrm{s}$ in autumn and 8-9 $\mathrm{s}$ in winter and spring, we can notice that most wave periods of up to $10 \mathrm{~s}$ are typical for eastern waves. Waves with longer periods ( $>10 \mathrm{~s}$ ) usually come from the southern (dominant) or southeastern quadrants.

From the $95^{\text {th }}$ percentile onwards, waves above $2.8 \mathrm{~m}$ are considered extreme for the region. When there are successive waves with Hs above $2.8 \mathrm{~m}$ for a minimum period of 12 hours, we identify an extreme event. Thus, with a total of 170 extreme events identified (an average of 12 events per year), in Table 2 we present the average duration of the events, as well as mean $\mathrm{Hs}$, mean Tp and mean Dp of these events in each year of the time series. In general, all 170 events are associated with waves from the south quadrant and with periods greater than $10 \mathrm{~s}$.

\section{Wave Power}

Even if summer has shown to be the season with the lowest wave force, with autumn and winter being the seasons with greatest amplitude in wave power (Figure 4), spatially, variability of the wave power distribution is small over the seasons (Figure $5 \mathrm{C}$ to F). This means that the regions where the waves are weakest or strongest are always the same: the portion facing the open sea receives stronger waves in all seasons of the year, while the portion facing the continent and the inner portion of Saco do Funil Bay receive the weakest waves throughout 


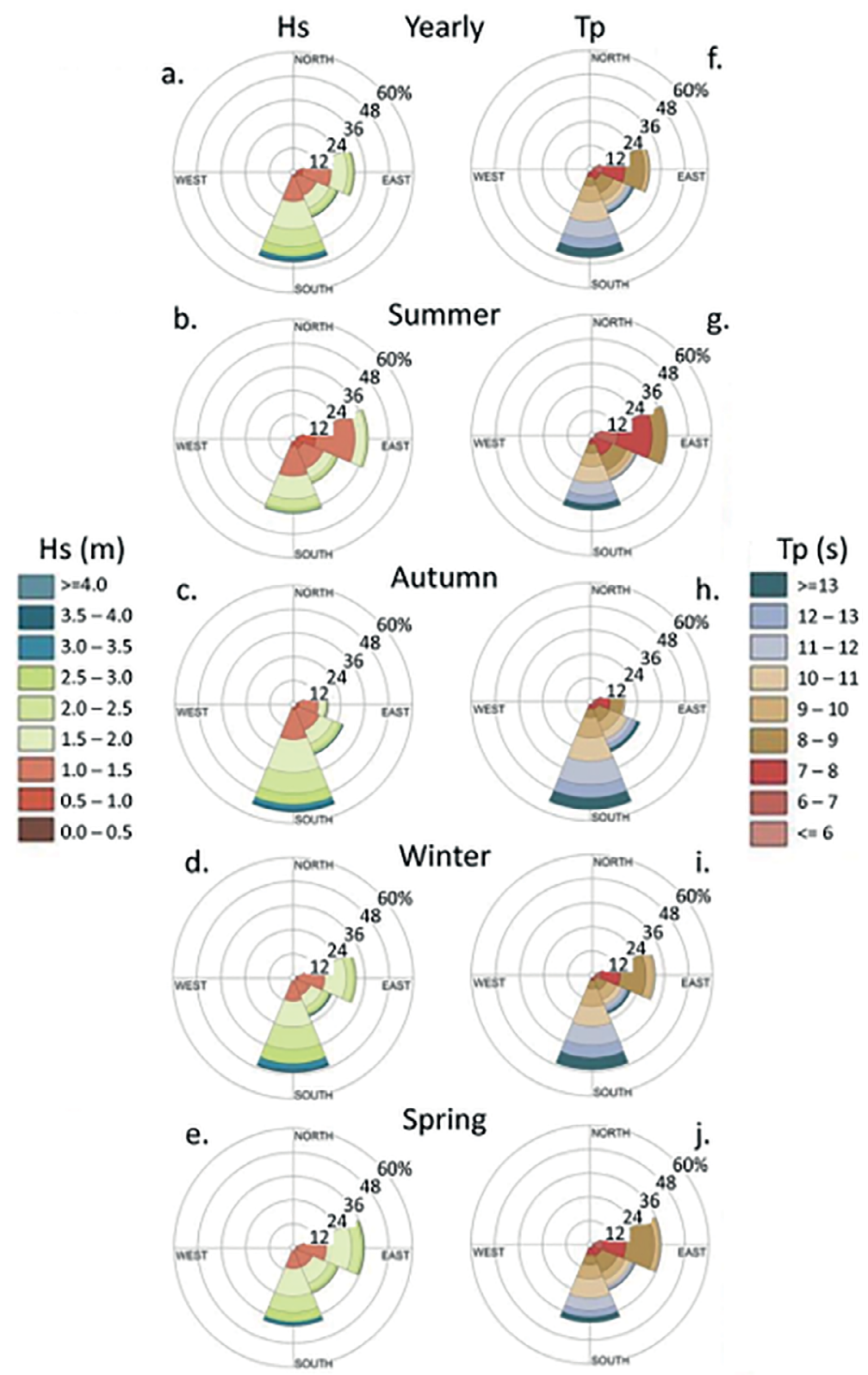

Figure 3. Directional histograms for the offshore yearly and seasonal wave climate for the period of 2005-2018. Right column: Significant wave height (a to e); Left column: Wave peak period ( $f$ to j).

the annual cycle. However, some subtle variations can be noted in wave power. During autumn and winter, the southern region of the portion facing the continent receives waves with a slightly greater force than during summer and spring. During autumn, the wave power also decreases at the outer portion of Saco do Funil Bay. Furthermore, in the portion facing the open sea there is a small bay whose wave power tends to be noticeably less, especially in summer and spring.
Yearly (Figure 5A), on the portion facing the open sea, waves arrive with the greatest power, between $11,000-17,000 \mathrm{~W} \mathrm{~m}^{-1}$. However, the small bay at the northern portion of the island has a lower mean wave force than at the other areas, varying approximately between 11,000 and $13,000 \mathrm{~W} \mathrm{~m}^{-1}$. On the other hand, regions where the waves arrive with less energy are in the innermost region of Saco do Funil Bay and in the portion facing the continent, although there is 
Table 2. Basic statistics on extreme events in the Alcatrazes wave climate, per year of the time series. Significant wave height $(\mathrm{Hs}-\mathrm{m})$, wave period $(\mathrm{Tp}-\mathrm{s})$ and direction (Dp - degrees North).

\begin{tabular}{|c|c|c|c|c|c|c|}
\hline Year & $N^{\circ}$ of Events & $\begin{array}{c}\text { Average } \\
\text { duration (h) }\end{array}$ & Mean Hs (m) & Mean Tp (s) & Mean Dp ( $\left.{ }^{\circ}\right)$ & $\begin{array}{l}\text { Mean Power } \\
\left(\mathbf{W ~ m}^{-1}\right)\end{array}$ \\
\hline 2005 & 8 & 36.75 & 3.16 & 10.44 & 179.56 & 103458.36 \\
\hline 2006 & 10 & 40.80 & 3.31 & 11.60 & 172.79 & 126746.76 \\
\hline 2007 & 16 & 29.75 & 3.33 & 11.25 & 185.93 & 125491.90 \\
\hline 2008 & 14 & 28.50 & 3.24 & 10.32 & 160.06 & 107269.47 \\
\hline 2009 & 18 & 29.00 & 3.18 & 11.63 & 179.04 & 116640.13 \\
\hline 2010 & 20 & 40.95 & 3.36 & 10.75 & 161.61 & 122085.24 \\
\hline 2011 & 12 & 37.00 & 3.34 & 11.98 & 173.31 & 134660.89 \\
\hline 2012 & 13 & 23.31 & 3.24 & 10.90 & 181.13 & 113226.22 \\
\hline 2013 & 17 & 27.35 & 3.22 & 11.00 & 180.88 & 112495.28 \\
\hline 2014 & 16 & 37.69 & 3.13 & 11.04 & 171.73 & 106874.27 \\
\hline 2015 & 8 & 25.88 & 3.16 & 10.97 & 175.67 & 108122.41 \\
\hline 2016 & 7 & 24.86 & 3.25 & 11.63 & 188.86 & 123347.73 \\
\hline 2017 & 6 & 38.00 & 3.34 & 11.10 & 141.84 & 122581.45 \\
\hline 2018 & 5 & 23.40 & 3.17 & 10.51 & 176.71 & 104624.86 \\
\hline
\end{tabular}

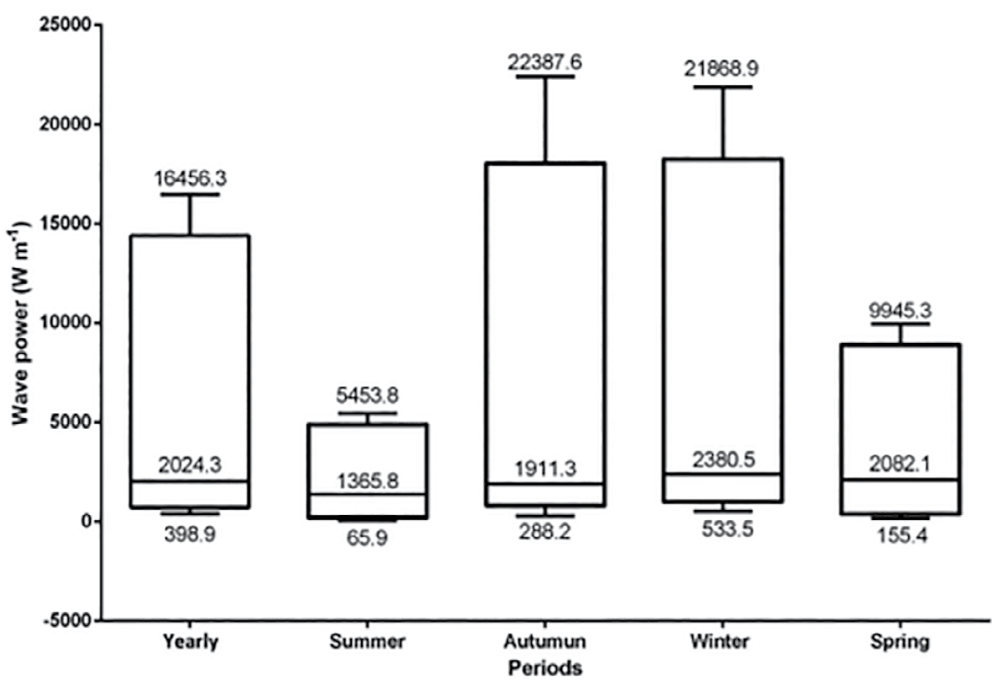

Figure 4. Box plots of yearly and seasonal wave power. Maximum, median and minimum wave power values are presented for each period.

an area of the southwestern region where the wave power varies between $2,000-4,000 \mathrm{~W} \mathrm{~m}^{-1}$ throughout the year. The same is observed in the outermost areas of Saco do Funil bay, annually and seasonally.

Extreme events (Figure 5B) reach the region from the south ( 90\%) and southeast (9.7\%). During such events, wave power is increased around the entire island, with the exception of the Saco do Funil Bay. However, as for the other scenarios, highest wave power is observed on the coast facing the open sea and at the southwest region of the island.

\section{DISCUSSION}

Wave exposure is decisive for the biotic and abiotic processes in archipelagos (e.g. Tolvanen and Suominen, 2005). Our results describe the wave power distribution around the main island of the Alcatrazes archipelago. Although being located on the continental shelf, there is an abrupt change in the bathymetry in its surroundings. As the waves approach the island and propagate from deeper to shallower waters, they change according to the bathymetry, dissipating energy by breaking or friction 

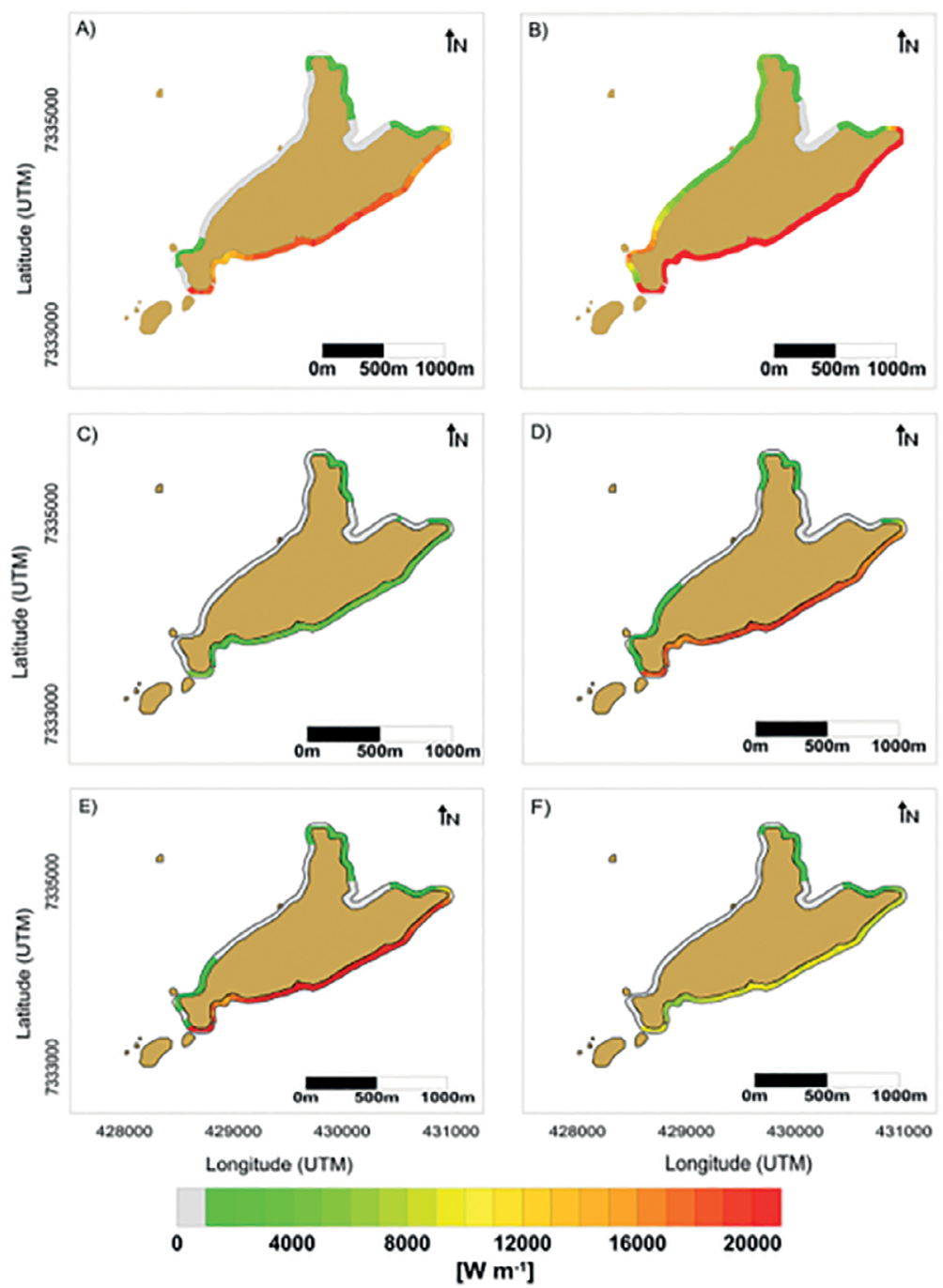

Figure 5. Seasonal wave power around Alcatrazes island. A) Yearly; B) Extremes; C) Summer; D) Autumn; E) Winter; F) Spring. Coordinates are given in UTM (Zone 23).

with the bottom, processes considered in the applied model. Also, as expected, the lee side of the island (coast facing toward the continent) showed major transformations in the offshore wave train, decreasing its heights and periods, resulting in lower wave forces on almost all the Alcatrazes island side facing the continent. Nevertheless, we were able to observe that the greatest wave force variation around Alcatrazes was mainly in the Saco do Funil Bay and at the southwestern region of the island. This is the result of the island's Y-shaped morphology, and dominant direction of incident waves, which vary throughout the seasons.
Although being the less energetic waves, easterly waves contribute most to the wave power along the Saco do Funil Bay. Since the mouth of Saco do Funil Bay faces northwards, even extreme waves and the most energetic southerly waves do not change the wave power along the margins of the bay. Therefore, during extreme events and during the energetic autumn months (Figure 3), this area of the island is subjected to lower wave power than during the periods when easterly waves dominate (spring and summer). Inside the bay, there is an inwards weakening of waves due to its $V$ shape that shadows the inner portions of the bay from the incoming waves. The 
outermost region, in turn, is an area of wave power concentration due to convergence by refraction. As in Saco do Funil Bay, on the coast facing the mainland, the lower wave forces in its central part are the result of wave shadowing, with diffracted waves reaching the region. Due to the dominant incidence direction of the most energetic waves, the southwestern region of the island becomes exposed to higher wave power, mainly during autumn and winter months.

During extreme events, when compared to the other scenarios, wave power is increased substantially around most of the island, mainly at its most exposed areas. As mentioned previously, only the Saco do Funil bay is protected from the most energetic southerly waves. The occurrence of extreme events in the region is important not only for present conditions, but also when considering increasing trends in the number and intensity of storms, added to sea level and ocean temperature rise as a result of climate change (e.g. Losada et al., 2019). A relationship between those events and an increase in wave energy has been described by several authors, including Reguero et al. (2019), who established a positive correlation between global ocean temperature and wave energy. Our results may provide important background information for other types of studies regarding climate change and its consequences for the Alcatrazes archipelago and similar environments elsewhere.

Additionally, our results provide relevant information regarding environmental influences on Alcatrazes biological communities. Stresses caused by incident waves, especially during extreme conditions, control the establishment, distribution, composition, and richness of marine organisms (Aued et al., 2018; Corte et al., 2017; Madin and Connolly, 2006; Williams et al., 2013). Friedlander et al. (2003) related higher species richness, biomass and diversity in fish assemblages in the sheltered locations in the Hawaiian archipelago. Similarly, the sheltered zones of the Alcatrazes island (Saco do Funil Bay and the Portinho face) seem to play an important role in local biodiversity, which does not exclude the relevance of exposed zones for conservation purposes. For instance, higher numbers of the two sea turtle species found in the Alcatrazes archipelago, Chelonia mydas and Eretmochelys imbricata, were recorded in sheltered zones, inversely related to rocky shore declivity (ICMBio, 2017). Our results highlight the differences in wave power that reach each portion of the island according to incoming wave characteristics and local morphology. In addition to the understanding of the seasonal wave power distribution around the island, such data forms background information for further studies that aim to assess different aspects of the functioning of this environment.

\section{CONCLUSION}

This study presents the seasonal wave power distribution around the Alcatrazes island. Through the application of a numerical model of wave propagation, we investigate the level of exposure to wave power distribution around the island. Wave climate characteristics interact with local topography, creating an irregular wave power distribution around the island. There is a clear difference between the exposed side of the island and its shadowed lee side, although most energetic waves from the southern quadrant can reach its southwestern area. The magnitude of wave power distribution varies throughout the year. Less energetic waves in summer contrast with the higher winter and autumn waves. Additionally, the island's Y-shaped morphology displays a bay facing north. This $V$-shaped bay is shadowed from the most energetic southerly waves, having its wave climate defined by the less energetic easterly waves, mainly during spring and summer months. Only the outermost portion of the bay is subjected to waves, while its innermost portion is well protected throughout the year. These findings are the first assessment of local wave climate and wave power distribution along the rocky shores of Alcatrazes island, providing important background information for the understanding of different aspects of the functioning of such environment.

\section{ACKNOWLEDGMENTS}

This work was partially funded by the Conselho Nacional de Desenvolvimento Científico e Tecnológico (CNPq - Award 439464/2018-8) and by the Coordenação de Aperfeiçoamento de Pessoal de Nível Superior - Brazil (CAPES - Finance Code 001). We thank Leandro Inoue Coelho for the photos of the Archipelago, used in Figure 1. ES is a CNPq research fellow. 


\section{AUTHOR CONTRIBUTIONS}

L.S.T.: Conceptualization; Data curation; Formal analysis; Investigation; Methodology; Software; Writing-original draft; Writing-review \& editing.

L.P.S.: Formal analysis; Investigation; Methodology; Writing-original draft; Writing-review \& editing.

N.T.H.: Investigation; Writing-review \& editing.

E.S.: Conceptualization; Formal analysis; Funding acquisition; Investigation; Methodology; Project administration; Resources; Software; Supervision; Writing-original draft; Writing-review \& editing.

\section{REFERENCES}

ALVES, J. H. G. M., RIBEIRO, E. O., MATHESON, G. S. G., LIMA, J. A. M. \& RIBEIRO, C. E. P. 2009. Reconstituição do clima de ondas no sul-sudeste Brasileiro entre 1997 e 2005. Revista Brasileira de Geofísica, 27(3), 427-445, DOI: https://doi.org/10.1590/ S0102-261X2009000300010

AMBROSIO, B. G., SOUSA, P. H. G. O., GAGLIARDI, M. H. \& SIEGLE, E. 2020. Wave energy distribution at inlet channel margins as a function of ebb tidal delta morphology: Cananéia Inlet, São Paulo, Brazil. Anais da Academia Brasileira de Ciências, 92(1), e20180677, DOI: https://doi.org/10.1590/00013765202020180677

ANASTASIOU, S. \& SYLAIOS, G. 2013. Nearshore wave field simulation at the lee of a large island. Ocean Engineering, 74, 6171, DOI: https://doi.org/10.1016/j.oceaneng.2013.09.013

ANDRADE, T. S., SOUSA, P. H. G. O. \& SIEGLE, E. 2019. Vulnerability to beach erosion based on a coastal processes approach. Applied Geography, 102, 12-19, DOI: https://doi.org/10.1016/j. apgeog.2018.11.003

AUED, A. W., SMITH, F., QUIMBAYO, J. P., CÂNDIDO, D. V, LONGO, G. O., FERREIRA, C. E. L. C., WITMAN, J. D., FLOETER, S. R. \& SEGAL, B. 2018. Patrones a gran escala de las comunidades bentónicas marinas en la Provincia de Brasil. Dryad Dataset, 1-15, DOI: https://doi.org/10.5061/dryad.f5s90

BENTO, A. R., MARTINHO, P. \& SOARES, C. G. 2018. Wave energy assessement for Northern Spain from a 33-year hindcast. Renewable Energy, 127, 322-333, DOI: https://doi. org/10.1016/j.renene.2018.04.049

BOOIJ, N., RIS, R. C. \& HOLTHUIJSEN, L. H. 1999. A third-generation wave model for coastal regions 1 . Model description and validation. Journal of Geophysical Research: Oceans, 104(C4), 7649-7666, DOI: https://doi.org/10.1029/98JC02622

CASTRO, B. M., MIRANDA, L. B., SILVA, L. S., FONTES, R. F. C., PEREIRA, A. F. \& COELHO, A. L. 2008. Processos físicos: hidrografia: circulação e transporte. In: PIRES-VANIN, A. M. S. (eds.). Oceanografia de um ecossistema subtropical - Plataforma de São Sebastião, SP. São Paulo: EDUSP, v. 1, pp. 59-121.

CAVALCANTI, I. F. A. \& KOUSKY, V. E. 2000. Climatology of South american cold fronts. Cachoeira Paulista: CPTEC/INPE, pp. 4-5.

CORTE, G. N., SCHLACHER, T. A., CHECON, H. H., BARBOZA, C. A. M., SIEGLE, E., COELMAN, R. A. \& AMARAL, A. C. Z. 2017. Storm effects on intertidal invertebrates: increased beta diversity of few individuals and species. PeerJ, 2017, 5, e3360, DOI: https://doi.org/10.7717/peerj.3360
DALBY, D. H., COWELL, E. B., SYRATT, W. J. \& CROTHERS, J. H. 1978. An exposure scale for marine shores in western Norway. Journal of the Marine Biological Association of the United Kingdom, 58(4), 975-996, DOI: https://doi.org/10.1017/ S0025315400056903

FRIEDLANDER, A. M., BROWN, E. K., JOKIEL, P. L., SMITH, W. R. \& RODGERS, K. S. 2003. Effects of habitat, wave exposure, and marine protected area status on coral reef fish assemblages in the Hawaiian archipelago. Coral Reefs, 22, 291-305, DOI: https://doi.org/10.1007/s00338-003-0317-2

FURTADO, V. V., RODRIGUES, M., CONTI, L. A. \& BARCELLOS, R. L. 2008. História evolutiva da região de São Sebastião, em Oceanografia de um ecossistema subtropical. In: PIRES-VANIN, A. M. S. (eds.). Oceanografia de um ecossistema subtropical - Plataforma de São Sebastião, SP. São Paulo: EDUSP, v. 1, pp. 25-37.

GALLO, B. M. G., CAMPOS, F. P., CHAGAS, C. A. \& BECKER, J. H. 2001. Levantamento preeliminar da ocorrência de tartarugas marinhas no Arquipélago dos Alcatrazes, litoral norte do Estado de São Paulo. In: XIV Semana Nacional de Oceonografia, Rio Grande: Fundação Universidade Federal de Rio Grande, pp. 14.

GAYLORD, B. 1999. Detailing agents of physical disturbance:Wave-induced velocities and accelerations on a rocky shore. Journal of Experimental Marine Biology and Ecology, 239(1), 85-124, DOl: https://doi. org/10.1016/S0022-0981(99)00031-3

GIBBONS, M. J. 1988. The impact of wave exposure on the meiofauna of Gelidium pristoides (Turner) Kuetzing (Gelidiales: Rhodophyta). Estuarine, Coastal and ShelfScience, 27(6), 581 593, DOI: https://doi.org/10.1016/0272-7714(88)90070-4

GIBRAN, F. Z. \& MOURA, R. L. 2012. The structure of rocky reef fish assemblages across a nearshore to coastal islands' gradient in Southeastern Brazil. Neotropical Ichthyology, 10(2), 369-82, DOI: https://doi.org/10.1590/S167962252012005000013

GONÇALVES, M., MARTINHO, P. \& SOARES, C. G. 2020. Wave energy assessment based on a 33-year hindcast for the Canary Islands. Renewable Energy, 152, 259-269, DOI: https://doi. org/10.1016/j.renene.2020.01.011

GRAMCIANINOV, C. B., CAMPOS, R. M., SOARES, C. G. \& CAMARGO, R. 2020. Extreme waves generated by cyclonic winds in the western portion of the South Atlantic Ocean. Ocean Engineering, 213, 107745, DOI: https://doi.org/https://doi. org/10.1016/j.oceaneng.2020.107745

HALL, A. M., HANSOM, J. D. \& JARVIS, J. 2008. Patterns and rates of erosion produced by high energy wave processes on hard rock headlands: the Grind of the Navir, Shetland, Scotland. Marine Geology, 248(1-2), 28-46, DOI: https://doi. org/10.1016/j.margeo.2007.10.007

HOFF, N. T., FIGUEIRA, R. C. L. \& ABESSA, D. M. S. 2015. Levels of metals, arsenic and phosphorus in sediments from two sectors of a Brazilian Marine Protected Area (Tupinambás Ecological Station). Marine Pollution Bulletin, 91(2), 403-409, DOI: https://doi.org/10.1016/j.marpolbul.2014.10.044

HOLTHUIJSEN, L. H. 2007. Waves in oceanic and coastal waters. Cambridge: Cambridge University Press, DOI: https://doi. org/10.1017/CBO9780511618536

HOLTHUIJSEN, L. H., BOOIJ, N. \& RIS, R. C. 1993. A spectral wave model for the coastal zone. In: CHAIRMAN, O. T. M. (ed.). Ocean wave measurement and analysis. New York: ASCE (American Society of Civil Engineers). 
ICMBIO (Instituto Chico Mendes de Conservação da Biodiversidade). 2012. Plano de ação nacional para a conservação da herpetofauna do sul do Brasil. Brasília: ICMBIO.

ICMBIO (Instituto Chico Mendes de Conservação da Biodiversidade). 2017. Plano de manejo da Estação Ecológica Tupinambás e refúgio de vida silvestre do arquipélago de Alcatrazes. Brasília: ICMBIO.

JONES, W. E. \& DEMETROPOULOS, A. 1968. Exposure to wave action: measurements of an important ecological parameter on rocky shores on Anglesey. Journal of Experimental Marine Biology and Ecology, 2(1), 46-63, DOI: https://doi. org/10.1016/0022-0981(68)90013-0

LANNA, E., ROSSI, A. L., CAVALCANTI, F. F., HAJDU, E. \& KLAUTAU, M. 2007. Calcareous sponges from São Paulo State, Brazil (Porifera: Calcarea: Calcinea) with the description of two new species. Journal of the Marine Biological Association of the United Kingdom, 87(6), 1553-1561, DOI: https://doi. org/10.1017/S0025315407056871

LAVENÈRE-WANDERLEY, A. A. \& SIEGLE, E. 2019. Wave-induced sediment mobility on a morphologically complex continental shelf: eastern Brazilian shelf. Geo-Marine Letters, 39 , 349-361, DOI: https://doi.org/10.1007/s00367-019-00580-4

LEMKE, N., CALLIARI, L. J., FONTOURA, J. A. S. \& AGUIAR, D. F. 2017. Wave directional measurement in Patos Lagoon, RS, Brazil. RBRH, 22(1), e1, DOI: https://doi.org/10.1590/23180331.011716053

LI, N., CHEUNG, K. F., STOPA, J. E., HSIAO, F., CHEN, Y. L., VEGA, L. \& CROSS, P. 2016. Thirty-four years of Hawaii wave hindcast from downscaling of climate forecast system reanalysis. Ocean Modelling, 100, 78-95, DOI: https://doi.org/10.1016/j. ocemod.2016.02.001

LOSADA, I. J., TOIMIL, A., MUÑOZ, A., GARCIA-FLETCHER, A. P. \& DIAZ-SIMAL, P. 2019. A planning strategy for the adaptation of coastal areas to climate change: the Spanish case. Ocean and Coastal Management, 182, 104983, DOI: https://doi. org/10.1016/j.ocecoaman.2019.104983

LUDKA, B. C., GUZA, R. T., O'REILLY, W. C., MERRIFIELD, M. A., FLICK, R. E., BAK, A. S., HESSER, T., BUCCIARELLI, R., OLFE, C., WOODWARD, B., BOYD, W., SMITH, K., OKIHIRO, M., GRENZEBACK, R., PARRY, L. \& BOYD, G. 2019. Sixteen years of bathymetry and waves at San Diego beaches. Scientific Data, 6, 161, DOI: https://doi.org/10.1038/s41597-019-0167-6

MADIN, J. S. \& CONNOLLY, S. R. 2006. Ecological consequences of major hydrodynamic disturbances on coral reefs. Nature, 444, 477-480, DOI: https://doi.org/10.1038/nature05328

MAHIQUES, M. M., SIEGLE, E., ALCÁNTARA-CARRIÓ, J., SILVA, F. G., SOUSA, P. H. G. O. \& MARTINS, C. C. 2016. The beaches of the State of São Paulo. In:SHORT, A. D. \& KLEIN, A. H. F. (orgs.). Brazilian beach systems. Dordrecht: Springer, pp. 397-418.

MAHIQUES, M. M., SOUSA, S. H. M., BURONE, L., NAGAI, R. H., SILVEIRA, I. C. A., FIGUEIRA, R. C. L., SOUTELINO, R. G., PONSONI, L. \& KLEIN, D. A. 2011. Radiocarbon geochronology of the sediments of the São Paulo Bight (southern Brazilian upper margin). Anais da Academia Brasileira de Ciências, 83(3), 817-834, DOI: https://doi.org/10.1590/S000137652011005000028

MAHIQUES, M. M., TASSINARI, C. C. G., MARCOLINI, S., VIOLANTE, R. A., FIGUEIRA, R. C. L., SILVEIRA, I. C. A., BURONE, L. \& MELLO E SOUSA, S. H. 2008. $\mathrm{Nd}$ and $\mathrm{Pb}$ isotope signatures on the Southeastern South American upper margin: Implications for sediment transport and source rocks. Marine Geology, 250(1-2), 51-63, DOI: https://doi.org/10.1016/j. margeo.2007.11.007
MARTINS, L., GARCIA, M. G. M. \& REVERTE, F. C. 2014. Geologia do arquipélago de Alcatrazes, litoral norte do Estado de São Paulo. In: Anais do $47^{\circ}$ Congresso Brasileiro de Geologia, 2126 Set. 2015, Salvador, BA, pp. 290.

MUSCAT, E., SAVIOLLI, J. Y., COSTA, A., CHAGAS, C. A., EUGÊNIO, M., ROTENBERG, E. L. \& OLMOS, F. 2014. Birds of the Alcatrazes archipelago and surrounding waters, São Paulo, southeastern Brazil. Check List, 10(4), 729-739, DOI: https:// doi.org/10.15560/10.4.729

NOGUEIRA, J. M. M., STEINER, T. M. \& AMARAL, A. C. Z. 2001. Descriptions of two new species of Eunice Cuvier, 1817 (Polychaeta: Eunicidae) from coastal islands of the State of São Paulo, Brazil. Scientia Marine, 65(1), 47-57.

ORTEGA-SÁNCHEZ, M., FACHIN, S., SANCHO, F. \& LOSADA, M. A. 2008. Relation between beachface morphology and wave climate at Trafalgar beach (Cádiz, Spain). Geomorphology, 99(1-4), 171-185, DOI: https://doi.org/10.1016/j.geomorph.2007.10.013

PAMPUCH, L. A. \& AMBRIZZI, T. 2015. Sistemas Frontais sobre a América do Sul Parte I: Climatologia e intervalo de passagem em dados de Reanálise I do NCEP/NCAR. Ciência e Natura, 38, 105-110.

PEGORELLI, C., DOTTORI, M. \& FORTES, J. F. 2018. Evaluating the gravity wave energy potential off the Brazilian coast. Brazilian Journal of Oceanography, 66(2), 220-233, DOI: https:// doi.org/10.1590/s1679-87592018011706602

PIANCA, C., MAZZINI, P. L. F. \& SIEGLE, E. 2010. Brazilian offshore wave climate based on NWW3 reanalysis. Brazilian Journal Oceanography, 58(1), 53-70, DOI: https://doi.org/10.1590/ s1679-87592010000100006

PIRES-VANIN, A. M. S., ROSSI-WONGTSCHOWSKI, C. L. D. B., AIDAR, E., MESQUITA, H. S. L., SOARES, L. S. H., KATSURAGAWA, M. \& MATSUURA, Y. 1993. Estrutura e função do ecossistema de plataforma continental do Atlântico sul brasileiro: síntese dos resultados. Publicação Especial do Instituto Oceanográfico, 10, 217-231.

PRATHEP, A., LEWMANOMONT, K. \& BUAPET, P. 2009. Effects of wave exposure on population and reproductive phenology of an algal turf, Gelidium pusillum (Gelidales, Rhodophyta), Songkhla, Thailand. Aquatic Botany, 90(2), 179-183, DOI: https://doi.org/10.1016/j.aquabot.2008.09.003

RATTRAY, A., IERODIACONOU, D. \& WOMERSLEY, T. 2015. Wave exposure as a predictor of benthic habitat distribution on high energy temperate reefs. Frontiers in Marine Science, 2 8, DOI: https://doi.org/10.3389/fmars.2015.00008

REBOITA, M. S., AMBRIZZI, T., SILVA, B. A., PINHEIRO, R. F. \& ROCHA, R. P. 2019. The South atlantic subtropical anticyclone: present and future climate. Frontiers Earth Science, 7, 8, DOI: https://doi.org/10.3389/feart.2019.00008

REBOITA, M. S., KRUSCHE, N., AMBRIZZI, T. \& ROCHA, R. P. 2015. Entendendo o tempo e o clima na América do Sul. Terrae Didatica, 8(1), 34-50, DOI: https://doi.org/10.20396/ td.v8i1.8637425

REGUERO, B. G., LOSADA, I. J. \& MÉNDEZ, F. J. 2019. A recent increase in global wave power as a consequence of oceanic warming. Nature Communications, 10, 205, DOI: https://doi. org/10.1038/s41467-018-08066-0

RIS, R. C. \& BOOIJ, N. 1999. A third-generation wave model for coastal regions 2. Verification. Journal of Geophysical Research, 104(C4), 7667-7681.

ROCHA, R. M. \& BONNET, N. Y. K. 2009. Ascídias (Tunicata, Ascidiacea) introduzidas no arquipélago de alcatrazes, São Paulo. Iheringia - Série Zoologia, 99(1), 27-35, DOI: https://doi. org/10.1590/s0073-47212009000100004 
ROLIM, F. A., LANGLOIS, T., RODRIGUES, P. F. C., BOND, T., MOTTA, F. S., NEVES, L. M. \& GADIG, O. B. F. 2019. Network of small notake marine reserves reveals greater abundance and body size of fisheries target species. PLoS One, 14(1), e0204970, DOI: https://doi.org/10.1371/journal.pone.0204970

ROLIM, F. A., RODRIGUES, P. F. \& GADIG, O. B. F. 2017. Peixes de recife rochoso: Estação Ecológica de Tupinambás, São Paulo. São Paulo: Anolis Books.

RUSU, E., PILAR, P. \& SOARES, C. G. 2008. Evaluation of the wave conditions in Madeira Archipelago with spectral models. Ocean Engineering, 35(13), 1357-1371, DOI: https://doi. org/10.1016/j.oceaneng.2008.05.007

SOUZA, R. B. \& ROBINSON, I. S. 2004. Lagrangian and satellite observations of the Brazilian Coastal Current. Continental Shelf Research, 24(2), 241-262, DOI: https://doi.org/10.1016/j. csr.2003.10.001

SHORT, A. D. \& KLEIN, A. H. F. 2016. Brazilian beach systems: review and overview. In: SHORT, A. D. \& KLEIN, A. H. F. (eds.). Coastal Research Library. New York: Springer, DOI: https:// doi.org/10.1007/978-3-319-30394-9_20

SIEGLE, E. \& COSTA, M. B. 2017. Nearshore wave power increase on reef-shaped coasts due to sea-level rise. Earth's Future, 5(10), 1054-65, DOI: https://doi.org/10.1002/2017EF000624

SILVA, F. G., SOUSA, P. H. G. O. \& SIEGLE, E. 2016. Longshore transport gradients and erosion processes along the Ilha Comprida (Brazil) beach system. Ocean Dynamics, 66, 853865, DOI: https://doi.org/10.1007/s10236-016-0956-9

ST. PIERRE, A. P. \& GAGNON, P. 2015. Wave action and starvation modulate intra-annual variation in displacement, microhabitat selection, and ability to contact prey in the common sea star, Asterias rubens Linnaeus. Journal of Experimental Marine Biology and Ecology, 467, 95-107, DOI: https://doi. org/10.1016/j.jembe.2015.03.009

STEIN, L. P. \& SIEGLE, E. 2019. Santos beach morphodynamics under high-energy conditions. Revista Brasileira de Geomorfologia, 20(3), 445-456, DOI: https://doi.org/10.20502/rbg. v20i3.1419

STOPA, J. E., CHEUNG, K. F. \& CHEN, Y. L. 2011. Assessment of wave energy resources in Hawaii. Renewable Energy, 36(2), 554-567, DOI: https://doi.org/10.1016/j.renene.2010.07.014
STOPA, J. E., FILIPOT, J. F., LI, N., CHEUNG, K. F., CHEN, Y. L. \& VEGA, L. 2013. Wave energy resources along the Hawaiian Island chain. Renewable Energy, 55, 305-321, DOI: https://doi. org/10.1016/j.renene.2012.12.030

SUN, Z., ZHANG, H., XU, D., LIU, X. \& DING, J. 2020. Assessment of wave power in the South China Sea based on 26-year high-resolution hindcast data. Energy, 197, 117218, DOI: https:// doi.org/10.1016/j.energy.2020.117218

THÉBAUDEAU, B., TRENHAILE, A. S. \& EDWARDS, R. J. 2013. Modelling the development of rocky shoreline profiles along the northern coast of Ireland. Geomorphology, 203, 66-78, DOI: https://doi.org/10.1016/j.geomorph.2013.03.027

TOLMAN, H. L. 1999. User manual and system documentation of WAVEWATCH-III version 1.18. College Park: U.S. Department of Commerce/National Oceanic and Atmospheric Administration/National Weather Service/National Centers for Environmental Prediction.

TOLVANEN, H. \& SUOMINEN, T. 2005. Quantification of openness and wave activity in archipelago environments. Estuarine, Coastal and Shelf Science, 64(2-3), 436-446, DOI: https:// doi.org/10.1016/j.ecss.2005.03.001

VANN JONES, E. C., ROSSER, N. J. \& BRAIN, M. J. 2018. Alongshore variability in wave energy transfer to coastal cliffs. Geomorphology, 322, 1-14, DOI: https://doi.org/10.1016/j.geomorph.2018.08.019

VISNADI, S. R. \& VITAL, D. M. 2001. Briófitas das ilhas de Alcatrazes, do Bom Abrigo, da Casca e do Castilho, estado de São Paulo, Brasil. Acta Botanica Brasilica, 15(2), 255-270, DOI: https://doi.org/10.1590/S0102-33062001000200011

WILLIAMS, G. J., SMITH, J. E., CONKLIN, E. J., GOVE, J. M., SALA, E. \& SANDIN, S. A. 2013. Benthic communities at two remote pacific coral reefs: effects of reef habitat, depth, and wave energy gradients on spatial patterns. PeerJ, 1, e81, DOI: https://doi.org/10.7717/peerj.81

WRIGHT, J. T., HOLMES, Z. C. \& BYERS, J. E. 2018. Stronger positive association between an invasive crab and a native intertidal ecosystem engineer with increasing wave exposure. Marine Environmental Research, 142, 124-129, DOI: https:// doi.org/10.1016/j.marenvres.2018.09.025 
SUPPLEMENTARY MATERIAL

Table S1. Modeled scenarios for the yearly time series. Significant wave height $(\mathrm{Hs}-\mathrm{m})$, wave period $(\mathrm{Tp}-\mathrm{s})$ and direction (Dp - degrees North).

\begin{tabular}{cccc}
\hline Hs & Tp & Dp & $\begin{array}{c}\text { Percentage } \\
\text { (\%) }\end{array}$ \\
\hline 1.25 & 7.71 & 94.55 & 14.3 \\
1.71 & 7.90 & 94.83 & 8 \\
1.26 & 09.02 & 133.66 & 9.8 \\
1.72 & 9.29 & 135.76 & 6.93 \\
1.28 & 10.27 & 178.47 & 12.25 \\
1.73 & 10.46 & 179.97 & 13.78 \\
2.22 & 10.68 & 181.36 & 8.68 \\
\hline
\end{tabular}

Table S2. Modeled scenarios for each season. Significant wave height $(\mathrm{Hs}-\mathrm{m})$, wave period $(\mathrm{Tp}-\mathrm{s})$ and direction (Dp - degrees North).

\begin{tabular}{|c|c|c|c|c|}
\hline & Hs & $T p$ & Dp & Percentage (\%) \\
\hline \multirow{9}{*}{ Summer } & 0.84 & 7.29 & 93.90 & 11.7 \\
\hline & 1.23 & 7.33 & 93.39 & 19.9 \\
\hline & 1.69 & 7.21 & 92.51 & 5.32 \\
\hline & 0.85 & 7.86 & 130.80 & 5.52 \\
\hline & 1.24 & 8.26 & 132.97 & 10.9 \\
\hline & 1.69 & 8.40 & 135.31 & 5.31 \\
\hline & 1.26 & 10.16 & 178.73 & 14.95 \\
\hline & 1.72 & 10.32 & 180.10 & 11.35 \\
\hline & 2.18 & 10.80 & 181.62 & 05.02 \\
\hline \multirow{7}{*}{ Autumn } & 1.22 & 7.81 & 98.60 & 9.68 \\
\hline & 1.24 & 9.60 & 134.41 & 11.4 \\
\hline & 1.72 & 9.76 & 136.50 & 7.34 \\
\hline & 1.28 & 10.45 & 178.53 & 15.1 \\
\hline & 1.73 & 10.73 & 180.57 & 16.73 \\
\hline & 2.22 & 10.77 & 182.27 & 10.92 \\
\hline & 2.72 & 11.23 & 181.96 & 5.6 \\
\hline \multirow{8}{*}{ Winter } & 1.27 & 7.99 & 93.27 & 13.3 \\
\hline & 1.72 & 8.27 & 94.55 & 10.7 \\
\hline & 1.27 & 9.50 & 134.96 & 8.11 \\
\hline & 1.73 & 9.83 & 135.77 & 6.25 \\
\hline & 1.29 & 10.52 & 177.99 & 9.9 \\
\hline & 1.75 & 10.60 & 179.57 & 13 \\
\hline & 2.24 & 10.89 & 181.51 & 11.17 \\
\hline & 2.72 & 11.30 & 181.28 & 6.73 \\
\hline \multirow{8}{*}{ Spring } & 1.27 & 7.89 & 94.53 & 14.66 \\
\hline & 1.72 & 7.87 & 95.03 & 12.53 \\
\hline & 2.19 & 7.66 & 95.60 & 5 \\
\hline & 1.29 & 8.70 & 132.19 & 8.9 \\
\hline & 1.71 & 09.02 & 135.38 & 8.85 \\
\hline & 1.29 & 9.87 & 178.48 & 9.12 \\
\hline & 1.73 & 10.09 & 179.50 & 13.9 \\
\hline & 2.22 & 10.16 & 179.72 & 8 \\
\hline
\end{tabular}

